\title{
Predictors of fossil fuel taxation attitudes across post-communist and other Europe
}

\author{
Jukka Sivonen \\ Department of Social Research, University of Turku, Turku, Finland
}

\begin{abstract}
Purpose - This study examines how the effects of three predictors, namely left-right political orientation, generalized trust and political trust, on fossil fuel taxation attitudes vary between post-communist and other European countries.

Design/methodology/approach - By using European Social Survey (ESS) Round 8 data and ordinary least squares (OLS) regression, this paper studied the effects of the hypothesized predictors on fossil fuel taxation attitudes across post-communist and other European countries. The countries were analyzed both in group and individually.

Findings - The results showed that stronger left-wing orientation, higher generalized trust and higher political trust predict more support for fossil fuel taxation at the country group level in both post-communist and other Europe. However, the effects were generally speaking less consistent and significant in the countries of the post-communist Europe. By and large, the effect of political trust was the most significant and universal. Originality/value - The findings contribute to the understanding how left-right political orientation and generalized trust have somewhat distinct effects on fossil fuel taxation attitudes in different European country contexts, while the effect of political trust is more universal across the continent.
\end{abstract}

Keywords Climate policy, Generalized trust, Post-communist countries, Political trust, Fossil fuel taxation, Left-right political orientation

Paper type Research paper

\section{Introduction}

Due to the progress of climate change there is urgent, increasing and global need to understand how support of carbon taxation is formed in different societal contexts (Carattini et al., 2019). One significant predictor for supporting climate policies is political orientation (Drews and van den Bergh, 2016). The cleavage between left and right has traditionally been the most important dividing line of politics. Left-wing ideology is typically associated with interests of the working class, relatively high taxation, equal income distribution and large welfare state, while right-wing ideology is often connected with lower taxation, smaller welfare state, less equal income distribution and benefits of the business life.

Later on, climate change and other environmental problems have added a new dimension to the political divide. While the public argument on tackling certain other environmental problems had already begun earlier, the breakthrough of climate change into political debates took place in the 1980s. When compared to right-wingers, supporters of left-wing are typically more concerned about the climate change (Clements, 2012; Kvaløy, et al., 2012) and more in favor of climate policies (Bechtel et al., 2019; Drews and van den Bergh, 2016; Neumayer, 2004).

(C) Jukka Sivonen. Published by Emerald Publishing Limited. This article is published under the Creative Commons Attribution (CC BY 4.0) licence. Anyone may reproduce, distribute, translate and create derivative works of this article (for both commercial and non-commercial purposes), subject to full attribution to the original publication and authors. The full terms of this licence may be seen at http:// creativecommons.org/licences/by/4.0/legalcode.

The research has been funded by the Tiina and Antti Herlin Foundation.
Predictors of fossil fuel taxation attitudes

Received 25 February 2020 Revised 20 April 2020 Accepted 21 April 2020

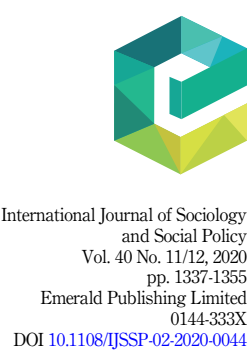


IJSSP

$40,11 / 12$

1338

In a closer look however, it seems that the described climate-related left-right divide applies to the non-post-communist Europe but not for post-communist countries (McCright et al., 2016). Even though post-communist states have stepped away from the communist rule, it appears that the period in question has - for its part - etched a distinctive influence on the political systems and attitudes among the post-communist countries. One reason for this could be that in the post-communist region liberalism is "consolidated" that is, market liberals are also liberal toward other societal issues (Gray, 1993; Whitefield, 2002). In turn, leftists in the post-communist countries are - contrary to other European leftists - relatively supportive to authoritarianism (Pop-Eleches and Tucker, 2019). Additionally, a study by McCright et al. (2016) finds that the left-wing orientation in the post-communist Europe predicts less willingness-to-pay for climate change mitigation. On the other hand, there is evidence that left-right political orientation is limited or insignificant factor in the post-communist region as it regards attitudes toward other type of environmental policies (Chaisty and Whitefield, 2015; McCright, et al., 2016; Smith and Mayer, 2019).

Based on the discussion above, the first research question asks (RQ1): does leftist political orientation predict less support for higher fossil fuel taxation in the post-communist Europe and more support in the other Europe, and are the findings consistent across individual countries?

Previous studies also show that support for environmental policies, such as environmental taxes, is related to trust in other people (Fairbrother, 2016; Smith and Mayer, 2018) and political institutions (e.g. Fairbrother et al., 2019; Harring, 2013). Without trust in other people, citizens may see each other as potential free-riders who do not contribute in solving collective problems, such as climate change (Jagers et al., 2019; Smith and Mayer, 2018; Sønderskov, 2011). Moreover, if citizens do not trust political institutions then they are less willing to support political reforms that include uncertain or risky outcomes (Rudolph, 2017; Trüdinger and Bollow, 2011).

Due to the differing levels of trust (e.g. Kouvo, 2011) and societal backgrounds between post-communist and other European countries, the effects of trust on the fossil fuel taxation attitudes may differ between the regions or countries in question. Hence, the second research question is articulated as follows (RQ2): are the hypothesized positive effects of generalized and political trust on supporting higher fossil fuel taxation consistent across Europe?

The predictors are analyzed both at the region level (comparing the total data, postcommunist and other Europe) and across individual countries. The study utilizes European Social Survey (ESS) Round 8 data and ordinary least squares (OLS) methodology.

\section{Predictors of support for higher fossil fuel taxation}

Left-right political orientation and citizens' fossil fuel taxation attitudes in the postcommunist and other European countries

Carbon and fuel taxes can be considered as relatively cost-effective climate policy instruments as they have successfully decreased emissions where they have been put in place (Sterner, 2007; Sterner and Robinson, 2018). When it comes to support of climate policy instruments there is an attitudinal gap between experts' and public's opinion. Experts tend to prefer carbon or fossil fuel taxation over subsidizing renewable energy and other "softer" policy measures, whereas citizens - in general - are more in favor of subsidizing renewable energy than carbon taxation (Drews and van den Bergh, 2016; Lucas, 2017). Public opinion has a habit of overestimating the possible negative outcomes of carbon taxation, such as job losses, and underestimating the advantages of decreased emissions (Carattini et al., 2019).

There are however, potentially influential factors that are related to the fossil fuel taxation attitudes. This study examines the significance of three factors: left-right political orientation, political trust and generalized trust. The dividing line between left and right can be characterized as "old-politics" cleavage that is related conflicts on social class and 
economic questions. Traditionally, left-wing orientation has promoted for higher taxes, more equal income redistribution and larger welfare state, whereas right-wing orientation has aimed for the opposite objectives. "New-politics" cleavage, instead, is considered to be more independent from the traditional social class structure, including questions such as minority rights and environmental protection (Hooghe et al., 2002). On the other hand, environmental questions are not apart from the left-right cleavage as left-wing orientation predicts typically more supportive attitudes toward environmental protection (e.g. Bechtel et al., 2019; Drews and van den Bergh, 2016).

Fossil fuel taxation includes elements from both old and new political cleavages. Higher fossil fuel taxation can decrease the amount of certain country's carbon dioxide $\left(\mathrm{CO}_{2}\right)$ emissions, while higher taxation on the one hand can gather more tax revenues to the National Economy, but can also - depending on the details - put stress on household economies (Klenert et al., 2018; Markandya and Ortiz, 2008). As climate protection requires interventionist policies from the state it is sometimes thought to be ill-fitting for the political right (Priest, 2016). Even though fuel or carbon taxes can advance development of the climatefriendly innovations (Hsu, 2016), one could interpret that higher tax on fossil fuels can hamper at least short-term success of the business life and thus, government should avoid raising energy taxation. As this viewpoint is more common among the rightists it is arguably one reason why they more often oppose environmental taxation than the leftists. The above arguments about the left and right ideology may not however, apply to the countries of the post-communist Europe.

The bygone communist era does not only affect the current public institutions but also people's attitudes in the countries of the post-communist Europe. According to Tavits and Letki (2009), left-wing parties in the post-communist countries have adapted ideological orientations that have traditionally characterized right-wing ideology. For instance, conservative values are more associated with the right-wing ideology in the Western Europe and with the left-wing ideology in the post-communist countries (Barni et al., 2016).

Chaisty and Whitefield (2015) explain the attitudinal differences in question with "sticky" values: the bygone communist era has shaped the way citizens view political issues, and the attitudes have sustained after the transition to capitalism possibly due to experiences related to the problems with democracy and high corruption. This can also be seen in terms of environmental attitudes. People in the post-communist countries view environmental question through a specific perspective that differs from other regions, and there is a relatively weak connection between environmental issues and other "more salient" political questions such as economic policy (Chaisty and Whitefield, 2015).

However, there is a reason to note that left- and right-wing politics have different meanings also between particular post-communist and other countries. In certain countries left-right cleavage is relatively unclear, of which Portugal is an extreme example (Freire and Belchior, 2013). Additionally, although right-wing is generally speaking related to the more liberal values in the post-communist Europe, but it is connected to more conservative and nationalistic values, for instance, in Hungary (Palonen, 2018) and post-East Germany (Kemper, 2015). On the other hand, in countries that are relatively dependent on fossil energy - such as Russia and Poland (IndexMundi, 2014) - the dependency may alter the relationship between political ideology and fossil fuel taxation attitudes (Harring et al., 2019).

Some studies have noticed differences between Western Europe and post-communist Europe in terms of environmental attitudes (Chaisty and Whitefield, 2015) and activism (Marquart-Pyatt, 2012). A cross-country study by McCright et al. (2016) shows that in Western Europe left-wing orientation predicts more willingness-to-pay for climate change mitigation, while in post-communist countries people with stronger left-wing orientation are less willing to pay for climate protection (McCright et al., 2016). As opposing climate change mitigation is typically associated to more conservative values it may be that in the post-
Predictors of fossil fuel taxation attitudes

1339 
IJSSP

$40,11 / 12$

1340 communist countries stronger left-wing orientation predicts less support for increasing fossil fuel taxation.

Based on the discussion above, first and second hypothesis are produced as follows:

H1. Across post-communist Europe, stronger left-wing orientation predicts less support for higher fossil fuel taxation.

H2. Across non-post-communist Europe, stronger left-wing orientation predicts more support for higher fossil fuel taxation.

\section{The significance of generalized and political trust}

Trust is an important aspect in the formation of citizens' environmental policy attitudes. Both generalized and political trust predict supportive attitude toward environmental protection, whereas mistrust has the opposite effect (e.g. Fairbrother, 2016; Smith and Mayer, 2018). Generalized trust can be defined as a belief that others do not want to harm us but want to look after our interests (Delhey and Newton, 2005). It has been identified as a crucial element of participating in solving large-N collective problems (Sønderskov, 2009, 2011) of which climate change is a model example (Jagers et al., 2019). People tend to cooperate when they expect others to do the same and do not consider each other as freeriders (Sønderskov, 2011).

In turn, political trust reflects "evaluations of whether or not political authorities and institutions are performing in accordance with the normative expectations held by the public" (Miller and Listhaug, 1990, p. 358). Trust in political institutions is especially crucial when it comes to supporting political reforms that include risks: people may lack profound knowledge about political questions, so when they evaluate how worthwhile certain reform is political trust plays a key role in the evaluation process (Rudolph, 2017; Trüdinger and Bollow, 2011). The importance of political trust in the support of carbon or fuel taxation has been shown in several studies (Fairbrother et al., 2019; Hammar and Jagers, 2006; Jagers et al., 2010). Political trust is a crucial element in supporting carbon taxation since even if people believe in climate change they may not support carbon taxation if they find political institutions unreliable (Harring, 2018).

There is evidence that there typically prevail relatively low levels of generalized and political trust in the countries with the communist past (e.g. Bjørnskov, 2007; Kouvo, 2011; Závecz, 2017). Due to the differing societal contexts, the relationship between trust and climate policy attitudes in the post-communist European countries - that have gone through extensive societal change and where often facing relatively high level of corruption (Chaisty and Whitefield, 2015) - may differ from other European countries. Therefore, it is interesting to examine how consistent the effects of generalized and political trust are on the fossil fuel taxation attitudes across post-communist and other European countries. To accomplish this aim, following hypotheses are formed:

H3. Across Europe, higher generalized trust predicts more support for increasing fossil fuel taxation.

H4. Across Europe, higher political trust predicts more support for increasing fossil fuel taxation.

\section{Data and research methodology}

This study utilizes data from ESS Round eight that were collected during 2016-2017 (ESS, 2018). The data enable comparative research on European nations with representative population samples. Since this study is concerning Europe, the data from Israel were not added to this analysis. The countries' sample sizes can be seen in Table 1. 


\begin{tabular}{lrrr}
\hline Country/region & $N$ & $\begin{array}{r}\text { Predictors of } \\
\text { fossil fuel } \\
\text { taxation }\end{array}$ \\
\hline Post-communist Europe & 14,392 & 2,269 & attitudes \\
The Czech Republic & 2019 & \\
Estonia & 1,614 & \\
Hungary & 2,122 & $\mathbf{1 3 4 1}$ \\
Lithuania & 1,694 & 937 & \\
Poland & 2,430 & \\
Post-East Germany & 1,307 & \\
Russia & 27,438 & \\
Slovenia & 2010 & \\
Other Europe & 1766 & \\
Austria & 1925 & \\
Belgium & 2070 & \\
Finland & 1959 & \\
France & 880 & \\
Great Britain & 2,757 & \\
Iceland & 2,626 & \\
Italy & 1,681 & \\
The Netherlands & 1,545 & \\
Norway & 1,270 & \\
Portugal & 1915 & \\
Post-West Germany & 1958 & Table 1. \\
Spain & 1,551 & Country/region \\
Sweden & 1,525 & sample sizes \\
Total & 41,830 & \\
\hline
\end{tabular}

After all, the data contains 23 countries (with exception of Germany that was classified to post-East and post-West Germany). In the Results section, the analysis is carried out at both country group level (the total data, post-communist Europe and other Europe) and across individual countries.

The dependent variable of this study is fossil fuel taxation attitude and independent variables are left-right political orientation, generalized trust and political trust, while control variables are the International Socio-Economic Index of Occupational Status (ISEI), age and gender. The control variables attempt to ensure that the possible differences between effects of independent variables are not related to differences in socioeconomic statuses, age or gender. Details of the dependent variable and independent and control variables are shown in Table 2.

The dependent variable measures attitudes toward higher fossil fuel taxation. The question for the respondents was: "To what extent are you in favor or against the following

\begin{tabular}{|c|c|c|c|c|c|c|c|}
\hline Variable & $n$ & Mean & $S D$ & Min & Max & Share $(\%)$ & \\
\hline Fossil fuel taxation attitude & 40,093 & 2.82 & 1.23 & 1 & 5 & & \\
\hline Right-left political orientation & 36,226 & 4.91 & 2.18 & 0 & 10 & & \\
\hline Generalized trust & 41,739 & 5.13 & 1.87 & 0 & 10 & & \\
\hline Political trust & 40,536 & 3.76 & 2.24 & 0 & 10 & & \\
\hline ISEI & 37,874 & 42.52 & 21.28 & 11.01 & 88.96 & & Table 2 \\
\hline Age & 41,702 & 47.35 & 18.70 & 15 & 100 & & Descriptive statistics of \\
\hline Gender & 41,821 & 1.52 & 0.50 & 1 & 2 & & the dependent variable \\
\hline 1 Male & & & & & & 47.34 & and independent and \\
\hline 2 Female & & & & & & 52.66 & control variables \\
\hline
\end{tabular}


IJSSP

$40,11 / 12$

1342

policies in [your country] to reduce climate change?" Then respondents were asked to opinion on "increasing taxes on fossil fuels, such as oil, gas and coal." For easier interpretation, the original answer scale was reversed so that higher number means more support for the increasing fossil fuel taxes: 1 = strongly against, $2=$ somewhat against, 3 = neither in favor nor against, $4=$ somewhat in favor and $5=$ strongly in favor. Distribution of the dependent variable by post-communist and other European countries is presented in Figure A1.

Left-right political orientation was measured by "placement on a left-right scale" and an option scale: $0=$ left $-10=$ right. Since left-wing ideology is assumed to have a positive connection with the dependent variable in most countries in the data, so to enable easier comparison of the effects of independent variables, the scale was reversed so that 0 means right-wing orientation and 10 means left-wing orientation.

Generalized trust is studied with statements and answer scales: (1) "most people can be trusted or you cannot be too careful," $0=$ you cannot be too careful $-10=$ most people can be trusted; (2) "most people try to take advantage of you or try to be fair," $0=$ most people try to take advantage of me $-10=$ most people try to be fair and (3) "most of the time people are helpful or mostly looking out for themselves," 0 = people mostly look out for themselves 10 = people mostly try to be helpful (e.g. Hooghe et al., 2009). In turn, political trust is measured by following variables: (1) trust in [country]'s Parliament, (2) trust in politicians and (3) trust in political parties (Listhaug and Ringdal, 2008). All these dimensions of political trust were originally measured with the following scale: $0=$ no trust at all $10=$ complete trust.

Cronbach's alpha value for the generalized trust sum variable is 0.77 and 0.91 for the political trust sum variable. The original scale of these sum variables was $0-30$. To enable easier comparison between the effects of the independent variables, the original values of generalized trust and political trust sum variables were divided by three. Values with decimals were rounded to the nearest integer value. Hence, the scale of all the three independent variables is $0-10$. Figures A2, A3, and A4 present the Pearson correlation values of independent variables and the dependent variable at the level of country averages.

The control variable ISEI is a continuous variable that is derived from the ISCOoccupation codes (Ganzeboom, 2010; Ganzeboom et al., 1992). The ISEI value consists of education, occupational status and earnings that are typical to each occupation that is included in ISCO-classification. The ESS Round eight data includes ISCO-08 codes (ESS, 2018). The conversion from ISCO-08 to ISEI was done with codes from Ganzeboom and Treiman (2010). Variable age ranges from 15 to 100. Both ISEI and age are centered to the mean of the country or region that the analysis in concerning. Gender, in turn, is classified as follows: $1=$ male and $2=$ female.

All the used variables were tested for multicollinearity and all the VIF-values were clearly under ten. The used research method was OLS regression (e.g. Eye and Schuster, 1998). In order to better compare the effects of independent variables, all the three independent variables, as well as control variables are included in the same regression models. To ensure that larger population or sample sizes do not overrule other ones, a weight was formed to secure that all countries are represented with equal amount of respondents (Dülmer, 2018; Skinner and Mason, 2012). Additionally, the analysis was also weighted with a post-stratification weight, provided by ESS (2014), which corrects biases that are related to the survey design and nonresponse rates. The study was executed with Stata, version 15.1.

\section{Results}

The purpose of this analysis was to explore how the effects of left-right political orientation, political trust and generalized trust on fossil fuel taxation attitudes varying across postcommunist and other European countries. The results presented in Figures 1, 2, and 3 test 

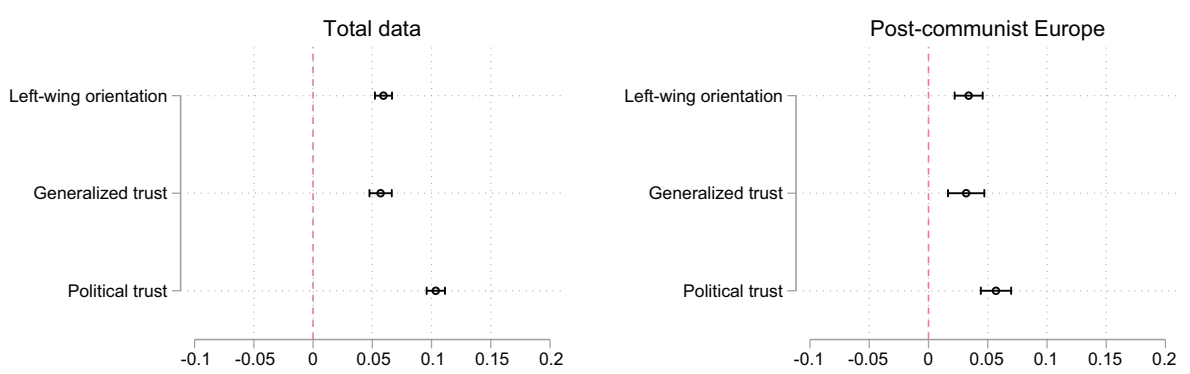

Predictors of fossil fuel taxation attitudes

\section{3}

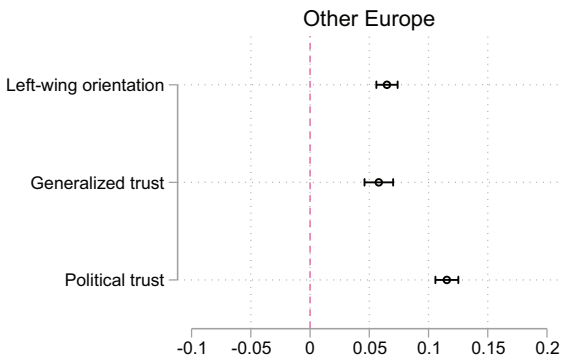

OLS regression: the effects of left-wing orientation, generalized trust, and political trust on attitudes towards higher fossil fuel taxes in the total data, postcommunist Europe, and other Europe. ISEI, age, and gender are controlled for $95 \%$ CI's
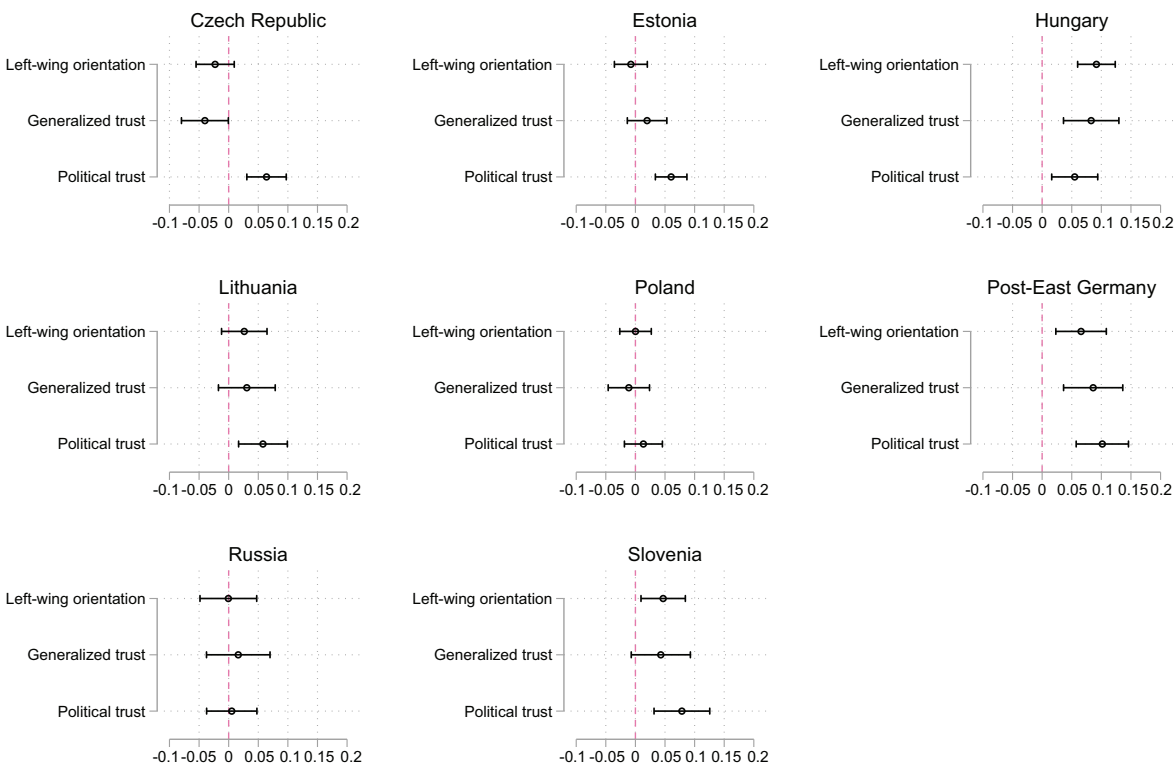

Figure 2.

OLS regression: the effects of left-wing orientation, generalized trust, and political trust on attitudes towards higher fossil fuel taxes in the post-communist countries. ISEI, age, and gender are controlled for $95 \%$ CI's

whether the four hypotheses are supported by the analysis. Regression Tables A1, A2, and A3 show more detailed information of the results presented in the figures in question. Figure 1 shows how leftist orientation, generalized trust and political trust predict attitudes toward higher fossil fuel taxation in the total data, post-communist Europe and other Europe. Figure 2 presents the effects of the independent variables on the dependent variable in the 
IJSSP

40,11/12
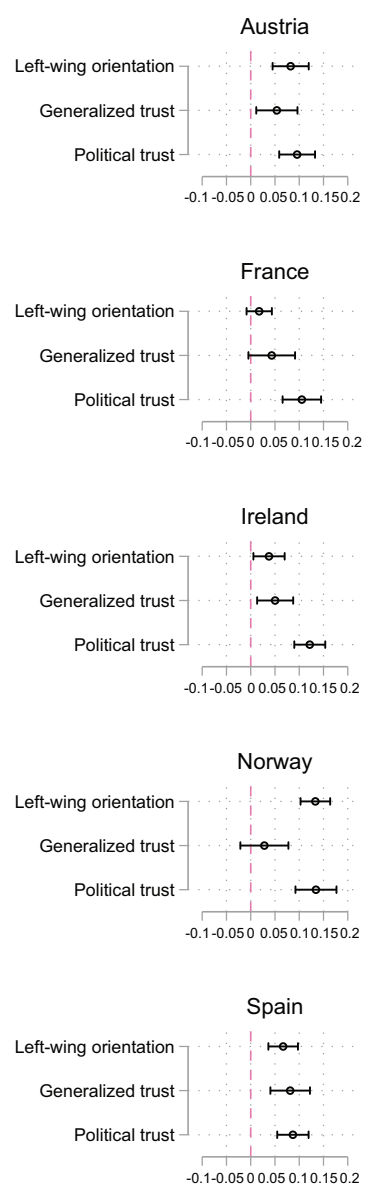
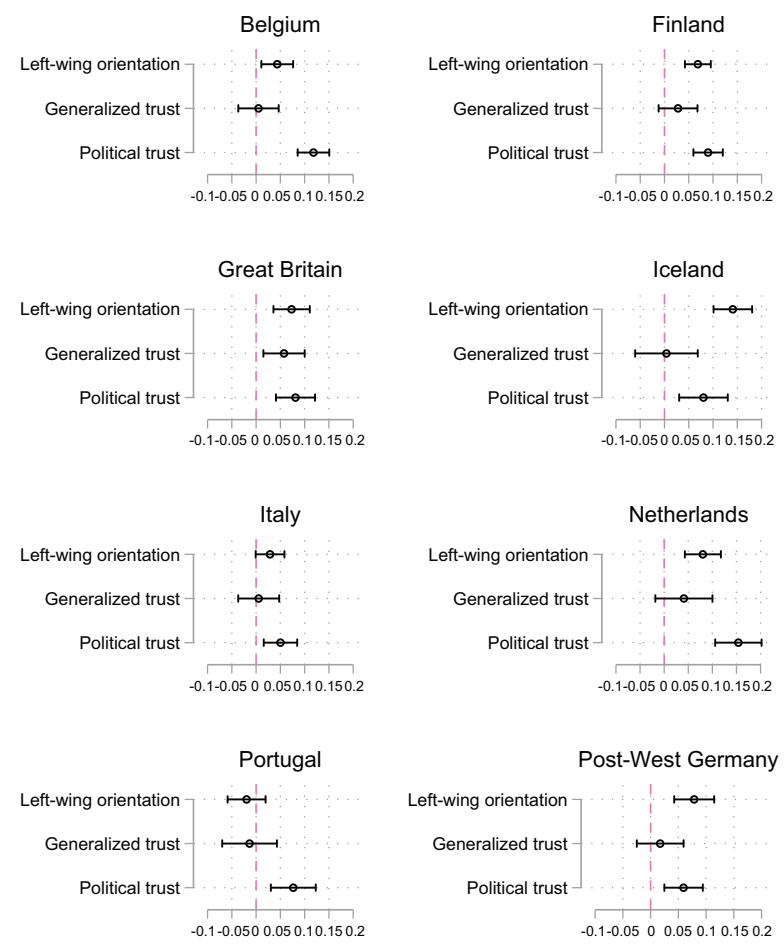

Post-West Germany

Figure 3.

OLS regression: the effects of left-wing orientation, generalized trust, and political trust on attitudes towards higher fossil fuel taxes in the non postcommunist countries. ISEI, age, and gender are controlled for 95\% Cl's post-communist European countries, including post-East Germany and Figure three illustrates the effects in question in the non-post-communist countries and post-West Germany.

First hypothesis (H1) predicted that across the post-communist Europe, stronger leftwing orientation predicts less support for higher fossil fuel taxes. When looking at the post-communist Europe as a whole in Figure 1 this hypothesis was not supported but quite the opposite: stronger left-wing orientation predicted more support toward fossil fuel taxation.

When the post-communist countries were explored separately in Figure 2, stronger leftwing orientation predicted slightly less support for the fossil fuel taxation in the Czech Republic, Estonia and Russia but the effects were not statistically significant. On the other hand, stronger left-wing orientation predicted more support for the taxation statistically significantly only in Hungary, post-East Germany and Slovenia.

Second hypothesis (H2) was that in the non-post-communist Europe, stronger left-wing orientation predicts more support for higher fossil fuel taxes. This assumption was supported when the region was analyzed as a whole (Figure 1). When non-post-communist countries were analyzed individually in Figure 3, stronger left-wing orientation predicted more support 
in most countries with exception of France, Italy and Portugal. In France and Italy, the effects in question were positive but statistically insignificant, and in Portugal the effect was slightly negative but insignificant.

Third, this study hypothesized (H3) that higher generalized trust predicts more support for increasing fossil fuel taxes across Europe. When countries were examined in groups, the assumption was supported in total data, in post-communist region and other Europe. The effect was slightly weaker in the post-communist than in other Europe. However, when countries were studied one by one the effect was statistically insignificant in most countries. Considering all countries in the used data, generalized trust predicted statistically significantly more support for higher fossil fuel taxes in Hungary, post-East Germany, Austria, Great Britain, Ireland, Spain and Switzerland. An exceptional case was the Czech Republic where higher generalized trust predicted statistically less significant support for higher fossil fuel taxation.

The fourth hypothesis (H4) assumed that higher political trust predicts more support for increasing fuel taxation across Europe. At the country group level, the hypothesis was supported in the total data, post-communist Europe and other Europe (Figure 1). However, the effect was weaker in the post-communist region. When countries were explored separately in Figure 3, the hypothesis was supported in every non-post-communist country and most of the post-communist countries. The exceptions were Poland and Russia where higher political trust did not predict statistically significantly more support for higher fossil fuel taxes.

\section{Conclusions}

This study examined the effects of left-right political orientation, generalized trust and political trust on fossil fuel taxation attitudes in different societal contexts: post-communist and other European countries. The analysis considered country groups as well as individual countries. The first research question (RQ1) asked whether stronger leftist political orientation predicts less support for fossil fuel taxation in the post-communist Europe and more support in other Europe and if the presumptions in question are consistent across individual countries. Unlike expected, this study was not in line with the previous finding that stronger left-wing orientation predicts less willingness-to-pay for climate protection in the post-communist Europe (McCright et al., 2016). Instead, stronger left-wing orientation predicted more support for higher fossil fuel taxation within the post-communist region as a whole but the effect was inconsistent between individual countries. In Slovenia, Hungary and post-East Germany people with stronger leftist orientation statistically significantly more supportive, but in other post-communist countries, the effect of left-right political orientation was not significant.

As expected, when looking at the non-post-communist Europe as a whole, stronger leftwing orientation predicted more support for fossil fuel taxation. When non-post-communist countries were studied individually only exceptions were France, Italy and Portugal, where the effect of left-right political orientation was insignificant.

Second research question (RQ2) attempted to find out whether the (hypothetically positive) effects of generalized and political trust on supporting fossil fuel taxation are consistent across Europe. When countries were grouped, higher generalized trust predicted more support for fossil fuel taxation in the total data, post-communist Europe and other Europe. However, when countries were examined one by one, the effect was insignificant in most countries. Exceptionally, the effect of generalized trust was statistically significantly negative in the Czech Republic. This finding would be an interesting topic for further investigation.

At the country group level, higher political trust predicted more support for higher fossil fuel taxation in the total data, post-communist Europe and other Europe. When countries
Predictors of fossil fuel taxation attitudes

1345 
IJSSP

$40,11 / 12$

1346

were explored separately, higher political trust was found to predict statistically significantly more support in every non-post-communist country and also in most of the post-communist countries.

Altogether, the positive effects of generalized and political trust on supporting fossil fuel taxation were not entirely consistent across Europe and the effects were not statistically significant in each country. The effect of political trust was, however, clearly more consistent across the studied countries than the effect of generalized trust.

Poland and Russia were the only countries where none of the three examined predictors had a significant effect. It may be that Poland's and Russia's high dependency on fossil energy (IndexMundi, 2014) alters the relation between the predictors and attitudes as the increase of fossil fuel taxation is presumably felt more directly in such countries. In Poland the support for the increase of fossil fuel taxation was also smallest of all countries (Figure A1). The link between fossil fuel dependency and carbon taxation attitudes would be a relevant topic for further research.

Figures A2, A3, and A4 imply that while higher generalized and political trust are clearly connected to stronger support for higher fossil fuel taxation at the country average level, leftright political orientation does not have the same type of relationship with the dependent variable. Hence, one can interpret that left-right political orientation is - especially in the nonpost-communist Europe - a significant factor in the formation of fossil fuel taxation attitudes at the individual level but hardly at the level of country averages. Instead, political trust appears to be a relevant factor at both country and individual level. At the level of country averages, generalized trust was slightly more correlated with support of fossil fuel taxation than political trust, but political trust was typically more significant factor at the individual level.

It seems that generalized trust and, in particular, left-right political orientation works in a different way between certain post-communist and other studied countries. When it comes to differing effects of the left and right political orientation one explanation could be that in, for example, Estonia, the Czech Republic and Russia the bygone communist era still influences how citizens understand left and right-wing politics. Arguably, the formation of fossil fuel taxation attitudes is relatively independent from the left-right political orientation in the countries in question. On the other hand, as stated earlier, the relationship between left-right political orientation and attitudes toward fossil fuel taxation was not significant in each nonpost-communist country either.

In all, this article supports the earlier research that stressed how strengthening of trust in political institutions is a valuable objective, among other things, in terms of promoting taxes that attempt to mitigate climate change (e.g. Smith and Mayer, 2018). However, to get more comprehensive understanding on the formation of carbon or fossil fuel taxation attitudes, more research is needed on the links between different country contexts and the attitude formation. There are obviously relevant factors that are related to fossil fuel taxation attitudes and were not added to this study. To get more trustworthy picture about formation of fossil fuel taxation attitudes, future studies could use longitudinal data and take different country-level conditions - such as the levels of current fossil fuel taxation and emissions into account.

\section{References}

Barni, D., Vieno, A. and Roccato, M. (2016), "Living in a non-communist versus in a post-communist European country moderates the relation between conservative values and political orientation: a multilevel study", European Journal of Personality, Vol. 30 No. 1, pp. 92-104.

Bechtel, M.M., Scheve, K.F. and van Lieshout, E. (2019), "What determines climate policy preferences if reducing greenhouse-gas emissions is a global public Good?”, SSRN, pp. 1-12, doi: 10.2139/ ssrn.3472314. 
Bjørnskov, C. (2007), "Determinants of generalized trust: a cross-country comparison”, Public Choice, Vol. 130 Nos 1-2, pp. 1-21.

Carattini, S., Kallbekken, S. and Orlov, A. (2019), "How to win public support for a global carbon tax", Nature, Vol. 565 No. 7739, pp. 289-291.

Chaisty, P. and Whitefield, S. (2015), "Attitudes toward the environment: are post-Communist societies (still) different?", Environmental Politics, Vol. 24 No. 4, pp. 598-616.

Clements, B. (2012), "Exploring public opinion on the issue of climate change in Britain", British Politics, Vol. 7 No. 2, pp. 183-202.

Delhey, J. and Newton, K. (2005), "Predicting cross-national levels of social trust: global pattern or Nordic exceptionalism?”, European Sociological Review, Vol. 21 No. 4, pp. 311-327.

Drews, S. and van den Bergh, J.C.J.M. (2016), "What explains public support for climate policies? A review of empirical and experimental studies", Climate Policy, Vol. 16 No. 7, pp. 855-876.

Dülmer, H. (2018), "A multilevel regression analysis on work Ethic", in Davidov, E., Schmidt, P., Billiet, J. and Meuleman, B. (Eds), Cross-Cultural Analysis: Methods and Applications, 2nd ed., Routledge, New York, NY, pp. 315-346.

ESS. (2014), "Weighting European social survey data", London, available at: http://www. europeansocialsurvey.org/docs/methodology/ESS_weighting_data_1.pdf $\quad$ (accessed 10 November 2018).

ESS. (2018), "The European social survey", available at: http://www.europeansocialsurvey.org/ (accessed 13 June 2018).

von Eye, A. and Schuster, C. (1998), Regression Analysis for Social Sciences, Academic Press, San Diego.

Fairbrother, M. (2016), "Trust and public support for environmental protection in diverse national contexts", Sociological Science, Vol. 3, pp. 359-382.

Fairbrother, M., Johansson Sevä, I. and Kulin, J. (2019), "Political trust and the relationship between climate change beliefs and support for fossil fuel taxes: evidence from a survey of 23 European countries", Global Environmental Change, Vol. 59, pp. 1-15, doi: 10.1016/j.gloenvcha.2019.102003.

Freire, A. and Belchior, A. (2013), "Ideological representation in Portugal: MPs'-Electors' linkages in terms of left-right placement and substantive meaning", Journal of Legislative Studies, Vol. 19 No. 1, pp. 1-21.

Ganzeboom, H.B.G. (2010), "A new international socio-economic index (ISEI) of occupational status for the international standard classification of occupation 2008 (ISCO-08) constructed with data from the ISSP 2002-2007", in Paper presented at Annual Conference of International Social Survey Programme, available at: https://www.researchgate.net/publication/242660186_A_new_ International_Socio-Economic_Index_ISEI_of_occupational_status_for_the_International_ Standard_Classification_of_Occupation_2008_ISCO-08_constructed_with_data_from_the_ ISSP_2002-2007 (accessed 22 November 2019).

Ganzeboom, H.B.G., De Graaf, P.M. and Treiman, D.J. (1992), "A standard international socio-economic index of occupational status”, Social Science Research, Vol. 21 No. 1, pp. 1-56.

Ganzeboom, H.B.G. and Treiman, D.J. (2010), "International Stratification and Mobility File: Conversion Tools.", Assignment of ISEI (International Socio-Economic Index of Occupational Status) Scores to ISCO-08 Codes, Department of Social Research Methodology, Amsterdam, available at: http://www.harryganzeboom.nl/isco08/ (accessed 22 November 2019).

Gray, J. (1993), "From post-communism to civil society: the reemergence of history and the decline of the western model”, Social Philosophy and Policy, Vol. 10 No. 2, pp. 26-50.

Hammar, H. and Jagers, S.C. (2006), "Can trust in politicians explain individuals' support for climate policy? The case of $\mathrm{CO}_{2}$ tax", Climate Policy, Vol. 5 No. 6, pp. 613-625.

Harring, N. (2013), "Understanding the effects of corruption and political trust on willingness to make economic sacrifices for environmental protection in a cross-national perspective”, Social Science Quarterly, Vol. 94 No. 3, pp. 660-671.
Predictors of fossil fuel taxation attitudes 
IJSSP

$40,11 / 12$

1348

Harring, N. (2018), "Trust and state intervention: results from a Swedish survey on environmental policy support”, Environmental Science and Policy, Vol. 82, pp. 1-8.

Harring, N., Jagers, S.C. and Matti, S. (2019), "The significance of political culture, economic context and instrument type for climate policy support: a cross-national study", Climate Policy, Vol. 19 No. 5, pp. 636-650.

Hooghe, L., Marks, G. and Wilson, C.J. (2002), "Does left/right structure party positions on European integration?”, Comparative Political Studies, Vol. 35 No. 8, pp. 965-989.

Hooghe, M., Reeskens, T., Stolle, D. and Trappers, A. (2009), "Ethnic diversity and generalized trust in Europe”, Comparative Political Studies, Vol. 42 No. 2, pp. 198-223.

Hsu, S.-L. (2016), "Carbon taxes”, in Farber, D.A. and Peeters, M. (Eds), Climate Change Law, Edward Elgar Publishing, Cheltenham, pp. 426-437.

IndexMundi (2014), "Fossil fuel energy consumption (\% of total) - country Ranking", available at: https://www.indexmundi.com/facts/indicators/EG.USE.COMM.FO.ZS/rankings (accessed 3 December 2019).

Jagers, S.C., Löfgren, Å. and Stripple, J. (2010), “Attitudes to personal carbon allowances: political trust, fairness and ideology", Climate Policy, Vol. 10 No. 4, pp. 410-431.

Jagers, S.C., Harring, N., Löfgren, A., Sjöstedt, M., Alpizar, F., Brülde, B., et al. (2019), "On the preconditions for large-scale collective action”, Ambio, pp. 1-15, doi: 10.1007/s13280-01901284-w.

Kemper, A. (2015), "AfD, Pegida and the new right in Germany", in Charalambous, G. (Ed.), The European Far Right: Historical and Contemporary Perspectives, Peace Research Institute Oslo (PRIO), Oslo, pp. 43-48.

Klenert, D., Mattauch, L., Combet, E., Edenhofer, O., Hepburn, C., et al. (2018), "Making carbon pricing work for citizens", Nature Climate Change, Vol. 8 No. 8, pp. 669-677.

Kouvo, A. (2011), "The sources of generalized trust and institutional confidence in Europe", Research on Finnish Society, Vol. 4, pp. 29-40.

Kvaløy, B., Finseraas, H. and Listhaug, O. (2012), "The publics' concern for global warming: a crossnational study of 47 countries", Journal of Peace Research, Vol. 49 No. 1, pp. 11-22.

Listhaug, O. and Ringdal, K. (2008), "Trust in political institutions", in Ervasti, H., Fridberg, T., Hjerm, M. and Ringdal, K. (Eds), Nordic Social Attitudes in a European Perspective, Edward Elgar, Cheltenham, pp. 131-151.

Lucas, G.M.J. (2017), "Behavioral public choice and the carbon tax", Utah Law Review, Vol. 69 No. 1, pp. 115-158.

Markandya, A. and Ortiz, R.A. (2008), "A note on the distributional effects of carbon taxes in the EU", in Gough, I., Meadowcroft, J., Dryzek, J., Gerhards, J., Lengfeld, H., Markandya, A. and Ortiz, R., JESP Symposium: Climate Change and Social Policy, Journal of European Social Policy, Vol. 18 No. 4, pp. 341-344.

Marquart-Pyatt, S.T. (2012), "Explaining environmental activism across countries", Society and Natural Resources, Vol. 25 No. 7, pp. 683-699.

McCright, A.M., Dunlap, R.E. and Marquart-Pyatt, S.T. (2016), "Political ideology and views about climate change in the European Union", Environmental Politics, Vol. 25 No. 2, pp. 338-358.

Miller, A.H. and Listhaug, O. (1990), "Political parties and confidence in government: a comparison of Norway, Sweden and the United States", British Journal of Political Science, Vol. 20 No. 3, pp. 357-386.

Neumayer, E. (2004), "The environment, left-wing political orientation and ecological economics", Ecological Economics, Vol. 51 Nos 3-4, pp. 167-175.

Palonen, E. (2018), "Performing the nation: the Janus-faced populist foundations of illiberalism in Hungary", Journal of Contemporary European Studies, Vol. 26 No. 3, pp. 308-321. 
Pop-Eleches, G. and Tucker, J.A. (2019), "Communist legacies and left-authoritarianism”, Comparative Political Studies, doi: 10.1177/0010414019879954.

Priest, S. (2016), Communicating Climate Change: The Path Forward, Palgrave Macmillan, London.

Rudolph, T.J. (2017), "Political trust as a heuristic", in Zmerli, S. and Meer, T.W.G. van der (Eds), Handbook on Political Trust, Edward Elgar, Cheltenham, pp. 197-211.

Skinner, C. and Mason, B. (2012), "Weighting in the regression analysis of survey data with a crossnational application", Canadian Journal of Statistics, Vol. 40 No. 4, pp. 697-711.

Smith, E.K. and Mayer, A. (2018), "A social trap for the climate? Collective action, trust and climate change risk perception in 35 countries", Global Environmental Change, Vol. 49, pp. 140-153.

Smith, E.K. and Mayer, A. (2019), "Anomalous Anglophones? Contours of free market ideology, political polarization, and climate change attitudes in English-speaking countries, Western European and post-Communist states", Climatic Change, Vol. 152 No. 1, pp. 17-34.

Sønderskov, K.M. (2009), "Different goods, different effects: exploring the effects of generalized social trust in large-N collective action", Public Choice, Vol. 140 Nos 1-2, pp. 145-160.

Sønderskov, K.M. (2011), "Explaining large- N cooperation: generalized social trust and the social exchange heuristic", Rationality and Society, Vol. 23 No. 1, pp. 51-74.

Sterner, T. (2007), "Fuel taxes: an important instrument for climate policy", Energy Policy, Vol. 35 No. 6, pp. 3194-3202.

Sterner, T. and Robinson, E.J.Z. (2018), "Selection and design of environmental instruments", in Dasgupta, P., Pattanayak, S.K. and Smith, V.K. (Eds), Handbook of Environmental Economics, Vol. 4, Elsevier, Amsterdam, pp. 231-284.

Tavits, M. and Letki, N. (2009), "When left is right: party ideology and policy in post-communist Europe”, American Political Science Review, Vol. 103 No. 4, pp. 555-569.

Trüdinger, E.M. and Bollow, U. (2011), "Evaluations of welfare state reforms in Germany: political trust makes a (big) difference", in Zmerli, S. and Hooghe, M. (Eds), Political Trust: Why Context Matters, ECPR Press, Colchester, pp. 187-212.

Whitefield, S. (2002), "Political cleavages and post-communist politics", Annual Review of Political Science, Vol. 5 No. 1, pp. 181-200.

Závecz, G. (2017), "Post-communist societies of central and Eastern Europe”, in Zmerli, S. and Meer, T.W.G. van der (Eds), Handbook on Political Trust, Edward Elgar, Cheltenham, pp. 440-460.
Predictors of fossil fuel taxation attitudes 
IJSSP

$40,11 / 12$

\section{Appendix}

1350

Table A1.

OLS regression: the effects of left-wing orientation, generalized trust, political trust, ISEI, age Other Europe and gender on attitudes toward higher fossil fuel taxes in the total data, post-communist Europe and other Europe

\begin{tabular}{|c|c|c|c|c|c|c|}
\hline Country/Region & Intercept/variable & Coef & SE & $p$-value & $n$ & $R^{2}$ \\
\hline \multirow[t]{7}{*}{ Total data } & Intercept & 2.3227 & 0.0311 & 0.000 & \multirow[t]{7}{*}{31,880} & \multirow[t]{7}{*}{0.0900} \\
\hline & Left-wing orientation & 0.0594 & 0.0037 & 0.000 & & \\
\hline & Generalized trust & 0.0570 & 0.0048 & 0.000 & & \\
\hline & Political trust & 0.1036 & 0.0039 & 0.000 & & \\
\hline & ISEI & 0.0064 & 0.0004 & 0.000 & & \\
\hline & Age & -0.0049 & 0.0004 & 0.000 & & \\
\hline & Gender (Ref. Male) & 0.0699 & 0.0153 & 0.000 & & \\
\hline \multirow[t]{7}{*}{ Post-communist Europe } & Intercept & 2.0666 & 0.0510 & 0.000 & \multirow[t]{7}{*}{9,852} & \multirow[t]{7}{*}{0.0296} \\
\hline & Left-wing orientation & 0.0339 & 0.0060 & 0.000 & & \\
\hline & Generalized trust & 0.0318 & 0.0078 & 0.000 & & \\
\hline & Political trust & 0.0569 & 0.0065 & 0.000 & & \\
\hline & ISEI & 0.0039 & 0.0006 & 0.000 & & \\
\hline & Age & -0.0035 & 0.0008 & 0.000 & & \\
\hline & Gender (Ref. Male) & 0.0768 & 0.0265 & 0.004 & & \\
\hline \multirow{7}{*}{ Other Europe } & Intercept & 1.7905 & 0.0397 & 0.000 & \multirow{7}{*}{22,028} & \multirow{7}{*}{0.1055} \\
\hline & Left-wing orientation & 0.0649 & 0.0046 & 0.000 & & \\
\hline & Generalized trust & 0.0580 & 0.0062 & 0.000 & & \\
\hline & Political trust & 0.1155 & 0.0049 & 0.000 & & \\
\hline & ISEI & 0.0071 & 0.0004 & 0.000 & & \\
\hline & Age & -0.0052 & 0.0005 & 0.000 & & \\
\hline & Gender (Ref. Male) & 0.0756 & 0.0185 & 0.000 & & \\
\hline
\end{tabular}

Table A2.

OLS regression: the effects of left-wing orientation, generalized trust, political trust, ISEI, age and gender on attitudes toward higher fossil fuel taxes in the postcommunist countries

\begin{tabular}{|c|c|c|c|c|c|c|}
\hline Country/Region & Intercept/Variable & Coef & $\mathrm{SE}$ & $p$-value & $n$ & $\mathrm{R} 2$ \\
\hline \multirow[t]{7}{*}{ The Czech Republic } & Intercept & 2.5873 & 0.1337 & 0.000 & \multirow[t]{7}{*}{1830} & \multirow[t]{7}{*}{0.0181} \\
\hline & Left-wing orientation & -0.0228 & 0.0164 & 0.165 & & \\
\hline & Generalized trust & -0.0401 & 0.0202 & 0.047 & & \\
\hline & Political trust & 0.0640 & 0.0170 & 0.000 & & \\
\hline & ISEI & -0.0006 & 0.0016 & 0.706 & & \\
\hline & Age & -0.0023 & 0.0022 & 0.296 & & \\
\hline & Gender (Ref. Male) & 0.2115 & 0.0658 & 0.001 & & \\
\hline \multirow[t]{7}{*}{ Estonia } & Intercept & 2.2321 & 0.1246 & 0.000 & \multirow[t]{7}{*}{1,590} & \multirow[t]{7}{*}{0.0456} \\
\hline & Left-wing orientation & -0.0077 & 0.0142 & 0.588 & & \\
\hline & Generalized trust & 0.0197 & 0.0170 & 0.247 & & \\
\hline & Political trust & 0.0604 & 0.0136 & 0.000 & & \\
\hline & ISEI & 0.0048 & 0.0012 & 0.000 & & \\
\hline & Age & -0.0037 & 0.0014 & 0.009 & & \\
\hline & Gender (Ref. Male) & 0.0899 & 0.0513 & 0.08 & & \\
\hline \multirow[t]{7}{*}{ Hungary } & Intercept & 1.7698 & 0.1483 & 0.000 & \multirow[t]{7}{*}{1,032} & \multirow[t]{7}{*}{0.0658} \\
\hline & Left-wing orientation & 0.0917 & 0.0162 & 0.000 & & \\
\hline & Generalized trust & 0.0828 & 0.0238 & 0.001 & & \\
\hline & Political trust & 0.0550 & 0.0198 & 0.006 & & \\
\hline & ISEI & 0.0064 & 0.0020 & 0.002 & & \\
\hline & Age & -0.0024 & 0.0024 & 0.323 & & \\
\hline & Gender (Ref. Male) & -0.0660 & 0.0836 & 0.430 & & \\
\hline
\end{tabular}

(continued) 


\begin{tabular}{|c|c|c|c|c|c|c|c|}
\hline Country/Region & Intercept/Variable & Coef & SE & $p$-value & $n$ & $\mathrm{R} 2$ & Predictors of \\
\hline \multirow[t]{7}{*}{ Lithuania } & Intercept & 2.3227 & 0.1681 & 0.000 & \multirow[t]{7}{*}{1,260} & \multirow[t]{7}{*}{0.0366} & taxatior \\
\hline & Left-wing orientation & 0.0264 & 0.0196 & 0.178 & & & \\
\hline & Generalized trust & 0.0307 & 0.0244 & 0.210 & & & \\
\hline & Political trust & 0.0580 & 0.0210 & 0.006 & & & \\
\hline & ISEI & 0.0054 & 0.0022 & 0.014 & & & \\
\hline & Age & -0.0072 & 0.0030 & 0.015 & & & 1351 \\
\hline & Gender (Ref. Male) & -0.1467 & 0.0846 & 0.083 & & & \\
\hline \multirow[t]{7}{*}{ Poland } & Intercept & 2.3035 & 0.1123 & 0.000 & \multirow[t]{7}{*}{1,180} & \multirow[t]{7}{*}{0.0078} & \\
\hline & Left-wing orientation & 0.0002 & 0.0136 & 0.988 & & & \\
\hline & Generalized trust & -0.0111 & 0.0178 & 0.533 & & & \\
\hline & Political trust & 0.0135 & 0.0163 & 0.408 & & & \\
\hline & ISEI & 0.0035 & 0.0014 & 0.015 & & & \\
\hline & Age & 0.0003 & 0.0018 & 0.870 & & & \\
\hline & Gender (Ref. Male) & 0.0813 & 0.0612 & 0.184 & & & \\
\hline \multirow[t]{7}{*}{ Post-East Germany } & Intercept & 1.5076 & 0.1639 & 0.000 & \multirow[t]{7}{*}{836} & \multirow{7}{*}{0.1470} & \\
\hline & Left-wing orientation & 0.0658 & 0.0217 & 0.003 & & & \\
\hline & Generalized trust & 0.0862 & 0.0255 & 0.001 & & & \\
\hline & Political trust & 0.1017 & 0.0225 & 0.000 & & & \\
\hline & ISEI & 0.0065 & 0.0021 & 0.002 & & & \\
\hline & Age & -0.0104 & 0.0024 & 0.000 & & & \\
\hline & Gender (Ref. Male) & 0.0412 & 0.0824 & 0.617 & & & \\
\hline \multirow[t]{7}{*}{ Russia } & Intercept & 2.4369 & 0.2029 & 0.000 & \multirow[t]{7}{*}{1,217} & \multirow[t]{7}{*}{0.0124} & \\
\hline & Left-wing orientation & -0.0005 & 0.0244 & 0.983 & & & \\
\hline & Generalized trust & 0.0162 & 0.0273 & 0.554 & & & \\
\hline & Political trust & 0.0052 & 0.0216 & 0.809 & & & \\
\hline & ISEI & 0.0017 & 0.0022 & 0.438 & & & \\
\hline & Age & -0.0018 & 0.0028 & 0.512 & & & \\
\hline & Gender (Ref. Male) & 0.2080 & 0.0931 & 0.026 & & & \\
\hline \multirow[t]{7}{*}{ Slovenia } & Intercept & 1.9454 & 0.1608 & 0.000 & \multirow[t]{7}{*}{907} & \multirow[t]{7}{*}{0.0558} & \\
\hline & Left-wing orientation & 0.0469 & 0.0191 & 0.014 & & & \\
\hline & Generalized trust & 0.0429 & 0.0254 & 0.092 & & & \\
\hline & Political trust & 0.0785 & 0.0240 & 0.001 & & & \\
\hline & ISEI & 0.0053 & 0.0021 & 0.011 & & & \\
\hline & Age & -0.0045 & 0.0024 & 0.064 & & & \\
\hline & Gender (Ref. Male) & 0.1423 & 0.0830 & 0.087 & & & Table A2. \\
\hline Country/Region & Intercept/variable & Coef & $\mathrm{SE}$ & $p$-value & $n$ & $R^{2}$ & \\
\hline \multirow[t]{7}{*}{ Austria } & Intercept & 1.6986 & 0.1352 & 0.000 & \multirow[t]{7}{*}{1,689} & \multirow[t]{7}{*}{0.1023} & \\
\hline & Left-wing orientation & 0.0823 & 0.0190 & 0.000 & & & \\
\hline & Generalized trust & 0.0539 & 0.0216 & 0.013 & & & \\
\hline & Political trust & 0.0957 & 0.0188 & 0.000 & & & \\
\hline & ISEI & 0.0042 & 0.0020 & 0.034 & & & \\
\hline & Age & -0.0072 & 0.0021 & 0.001 & & & \\
\hline & Gender (Ref. Male) & 0.0647 & 0.0714 & 0.365 & & & Table A3. \\
\hline \multirow[t]{8}{*}{ Belgium } & Intercept & 2.0022 & 0.1404 & 0.000 & 1,518 & 0.0967 & OLS regression: the \\
\hline & Left-wing orientation & 0.0436 & 0.0167 & 0.009 & & & effects of left-wing \\
\hline & Generalized trust & 0.0050 & 0.0212 & 0.815 & & & orientation, \\
\hline & Political trust & 0.1182 & 0.0166 & 0.000 & & & generalized trust, \\
\hline & ISEI & 0.0088 & 0.0014 & 0.000 & & & political trust, ISEI, age \\
\hline & Age & -0.0094 & 0.0018 & 0.000 & & & and gender on attitudes \\
\hline & Gender (Ref. Male) & 0.0257 & 0.0606 & 0.671 & & & $\begin{array}{l}\text { toward higher fossil } \\
\text { fuel taxes in the non- }\end{array}$ \\
\hline & & & & & & zued) & $\begin{array}{r}\text { post-communist } \\
\text { countries }\end{array}$ \\
\hline
\end{tabular}


IJSSP

40,11/12

\begin{tabular}{|c|c|c|c|c|c|c|}
\hline Country/Region & Intercept/variable & Coef & SE & $p$-value & $n$ & $R^{2}$ \\
\hline \multirow[t]{7}{*}{ Finland } & Intercept & 2.4285 & 0.1399 & 0.000 & 1716 & 0.0722 \\
\hline & Left-wing orientation & 0.0687 & 0.0136 & 0.000 & & \\
\hline & Generalized trust & 0.0279 & 0.0204 & 0.171 & & \\
\hline & Political trust & 0.0898 & 0.0155 & 0.000 & & \\
\hline & ISEI & 0.0070 & 0.0011 & 0.000 & & \\
\hline & Age & -0.0006 & 0.0014 & 0.696 & & \\
\hline & Gender (Ref. Male) & 0.0599 & 0.0522 & 0.251 & & \\
\hline \multirow[t]{7}{*}{ France } & Intercept & 1.9707 & 0.1321 & 0.000 & 1751 & 0.0720 \\
\hline & Left-wing orientation & 0.0175 & 0.0133 & 0.188 & & \\
\hline & Generalized trust & 0.0433 & 0.0245 & 0.077 & & \\
\hline & Political trust & 0.1054 & 0.0202 & 0.000 & & \\
\hline & ISEI & 0.0066 & 0.0016 & 0.000 & & \\
\hline & Age & -0.0084 & 0.0018 & 0.000 & & \\
\hline & Gender (Ref. Male) & -0.0829 & 0.0646 & 0.200 & & \\
\hline \multirow{7}{*}{ Great Britain } & Intercept & 1.8938 & 0.1631 & 0.000 & 1,590 & 0.0753 \\
\hline & Left-wing orientation & 0.0732 & 0.0191 & 0.000 & & \\
\hline & Generalized trust & 0.0576 & 0.0217 & 0.008 & & \\
\hline & Political trust & 0.0812 & 0.0205 & 0.000 & & \\
\hline & ISEI & 0.0036 & 0.0015 & 0.018 & & \\
\hline & Age & -0.0102 & 0.0020 & 0.000 & & \\
\hline & Gender (Ref. Male) & 0.0558 & 0.0656 & 0.395 & & \\
\hline \multirow[t]{7}{*}{ Iceland } & Intercept & 2.0812 & 0.2231 & 0.000 & 788 & 0.1131 \\
\hline & Left-wing orientation & 0.1408 & 0.0203 & 0.000 & & \\
\hline & Generalized trust & 0.0041 & 0.0329 & 0.902 & & \\
\hline & Political trust & 0.0803 & 0.0255 & 0.002 & & \\
\hline & ISEI & 0.0075 & 0.0019 & 0.000 & & \\
\hline & Age & -0.0001 & 0.0024 & 0.978 & & \\
\hline & Gender (Ref. Male) & 0.1685 & 0.0853 & 0.049 & & \\
\hline \multirow[t]{7}{*}{ Ireland } & Intercept & 1.8400 & 0.1363 & 0.000 & 1975 & 0.1155 \\
\hline & Left-wing orientation & 0.0377 & 0.0164 & 0.022 & & \\
\hline & Generalized trust & 0.0503 & 0.0189 & 0.008 & & \\
\hline & Political trust & 0.1217 & 0.0163 & 0.000 & & \\
\hline & ISEI & 0.0102 & 0.0014 & 0.000 & & \\
\hline & Age & -0.0100 & 0.0019 & 0.000 & & \\
\hline & Gender (Ref. Male) & -0.1636 & 0.0615 & 0.008 & & \\
\hline \multirow[t]{7}{*}{ Italy } & Intercept & 2.2529 & 0.1187 & 0.000 & 1,289 & 0.0365 \\
\hline & Left-wing orientation & 0.0287 & 0.0151 & 0.057 & & \\
\hline & Generalized trust & 0.0054 & 0.0215 & 0.803 & & \\
\hline & Political trust & 0.0503 & 0.0176 & 0.004 & & \\
\hline & ISEI & 0.0073 & 0.0018 & 0.000 & & \\
\hline & Age & -0.0033 & 0.0020 & 0.095 & & \\
\hline & Gender (Ref. Male) & 0.0963 & 0.0719 & 0.180 & & \\
\hline \multirow[t]{7}{*}{ The Netherlands } & Intercept & 1.5407 & 0.1819 & 0.000 & 1,477 & 0.1158 \\
\hline & Left-wing orientation & 0.0803 & 0.0190 & 0.000 & & \\
\hline & Generalized trust & 0.0410 & 0.0302 & 0.175 & & \\
\hline & Political trust & 0.1540 & 0.0245 & 0.000 & & \\
\hline & ISEI & 0.0082 & 0.0017 & 0.000 & & \\
\hline & Age & -0.0029 & 0.0021 & 0.177 & & \\
\hline & Gender (Ref. Male) & 0.0171 & 0.0718 & 0.811 & & \\
\hline
\end{tabular}

(continued)

Table A3. 


\begin{tabular}{|c|c|c|c|c|c|c|c|}
\hline Country/Region & Intercept/variable & Coef & SE & $p$-value & $n$ & $R^{2}$ & Predictors of \\
\hline \multirow[t]{7}{*}{ Norway } & Intercept & 1.5204 & 0.1781 & 0.000 & \multirow[t]{7}{*}{1,433} & \multirow[t]{7}{*}{0.1514} & taxation \\
\hline & Left-wing orientation & 0.1332 & 0.0156 & 0.000 & & & \\
\hline & Generalized trust & 0.0281 & 0.0252 & 0.265 & & & \\
\hline & Political trust & 0.1344 & 0.0215 & 0.000 & & & \\
\hline & ISEI & 0.0086 & 0.0015 & 0.000 & & & \\
\hline & Age & 0.0003 & 0.0018 & 0.869 & & & 1353 \\
\hline & Gender (Ref. Male) & 0.2588 & 0.0658 & 0.000 & & & \\
\hline \multirow[t]{7}{*}{ Portugal } & Intercept & 2.4291 & 0.1776 & 0.000 & \multirow{7}{*}{1,051} & \multirow[t]{7}{*}{0.0520} & \\
\hline & Left-wing orientation & -0.0196 & 0.0199 & 0.325 & & & \\
\hline & Generalized trust & -0.0134 & 0.0287 & 0.640 & & & \\
\hline & Political trust & 0.0766 & 0.0236 & 0.001 & & & \\
\hline & ISEI & 0.0103 & 0.0023 & 0.000 & & & \\
\hline & Age & -0.0020 & 0.0027 & 0.468 & & & \\
\hline & Gender (Ref. Male) & 0.1192 & 0.0978 & 0.223 & & & \\
\hline \multirow[t]{7}{*}{ Post-West Germany } & Intercept & 2.3104 & 0.1356 & 0.000 & \multirow[t]{7}{*}{1702} & \multirow[t]{7}{*}{0.0517} & \\
\hline & Left-wing orientation & 0.0785 & 0.0184 & 0.000 & & & \\
\hline & Generalized trust & 0.0173 & 0.0215 & 0.421 & & & \\
\hline & Political trust & 0.0594 & 0.0177 & 0.001 & & & \\
\hline & ISEI & 0.0044 & 0.0015 & 0.004 & & & \\
\hline & Age & -0.0046 & 0.0017 & 0.006 & & & \\
\hline & Gender (Ref. Male) & 0.0304 & 0.0589 & 0.606 & & & \\
\hline \multirow[t]{7}{*}{ Spain } & Intercept & 1.4998 & 0.1290 & 0.000 & \multirow[t]{7}{*}{1,399} & \multirow[t]{7}{*}{0.0777} & \\
\hline & Left-wing orientation & 0.0669 & 0.0155 & 0.000 & & & \\
\hline & Generalized trust & 0.0813 & 0.0208 & 0.000 & & & \\
\hline & Political trust & 0.0870 & 0.0165 & 0.000 & & & \\
\hline & ISEI & 0.0069 & 0.0016 & 0.000 & & & \\
\hline & Age & -0.0065 & 0.0021 & 0.002 & & & \\
\hline & Gender (Ref. Male) & -0.0308 & -0.0308 & 0.638 & & & \\
\hline \multirow[t]{7}{*}{ Sweden } & Intercept & 2.2740 & 0.2021 & 0.000 & \multirow[t]{7}{*}{1,380} & \multirow[t]{7}{*}{0.1339} & \\
\hline & Left-wing orientation & 0.0854 & 0.0172 & 0.000 & & & \\
\hline & Generalized trust & 0.0105 & 0.0308 & 0.734 & & & \\
\hline & Political trust & 0.1233 & 0.0232 & 0.000 & & & \\
\hline & ISEI & 0.0070 & 0.0019 & 0.000 & & & \\
\hline & Age & -0.0073 & 0.0021 & 0.001 & & & \\
\hline & Gender (Ref. Male) & 0.3433 & 0.0772 & 0.000 & & & \\
\hline \multirow[t]{7}{*}{ Switzerland } & Intercept & 1.6632 & 0.1572 & 0.000 & \multirow[t]{7}{*}{1,270} & \multirow[t]{7}{*}{0.1298} & \\
\hline & Left-wing orientation & 0.1506 & 0.0143 & 0.000 & & & \\
\hline & Generalized trust & 0.0560 & 0.0209 & 0.008 & & & \\
\hline & Political trust & 0.0961 & 0.0194 & 0.000 & & & \\
\hline & ISEI & 0.0065 & 0.0015 & 0.000 & & & \\
\hline & Age & -0.0024 & 0.0017 & 0.165 & & & \\
\hline & Gender (Ref. Male) & -0.0103 & 0.0622 & 0.868 & & & Table A3. \\
\hline
\end{tabular}


IJSSP

40,11/12

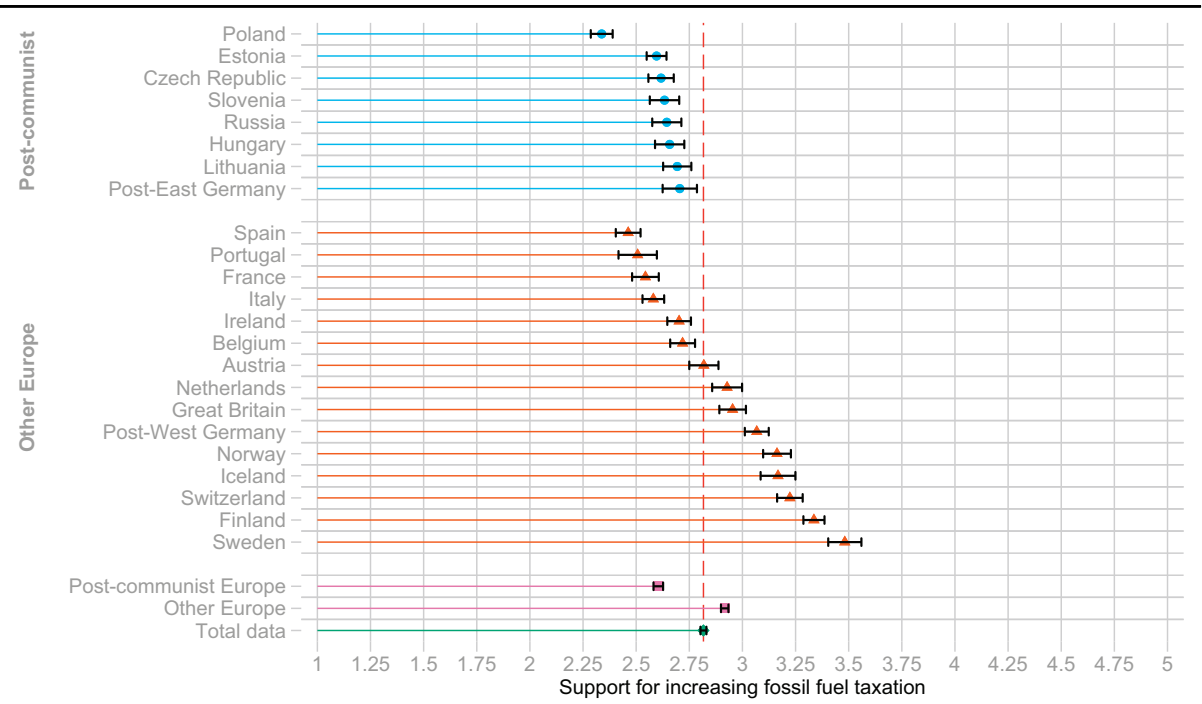

Figure A1.

Fossil fuel taxation attitudes by countries of the post-communist Europe and other Europe. Dashed vertical line presents mean of the total data. 95\% Cl's

Figure A2.

Country level averages of right-left orientation and fossil fuel taxation attitudes. Right $=0$ Left $=10$

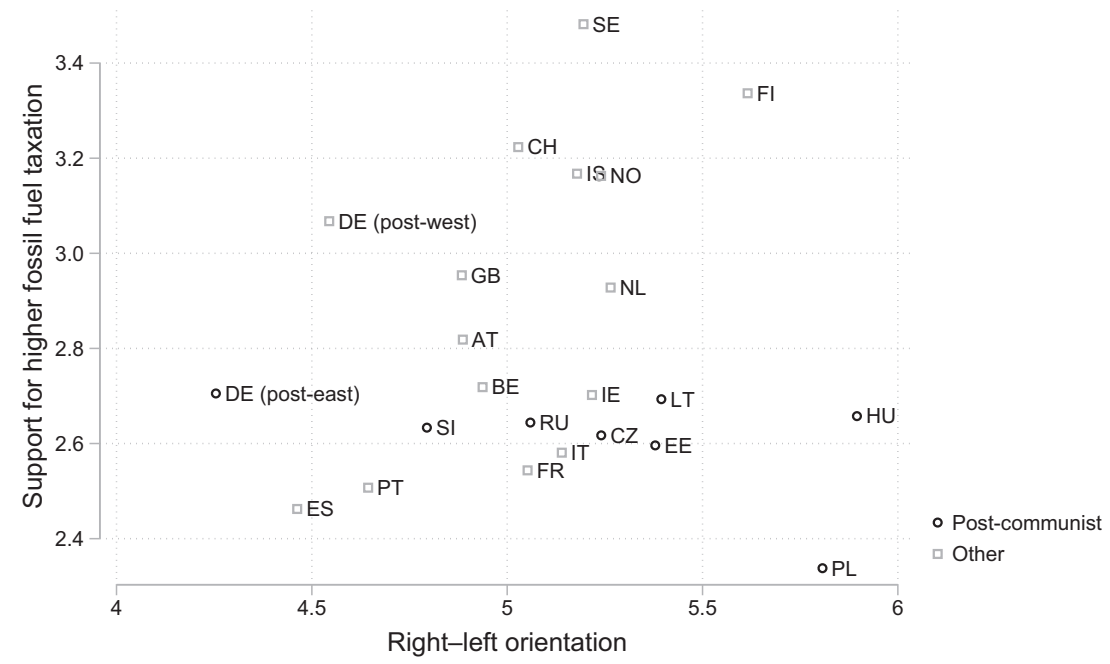

Pearson correlation coefficient between $X$ and $Y$ variables (country averages): 0.0618 


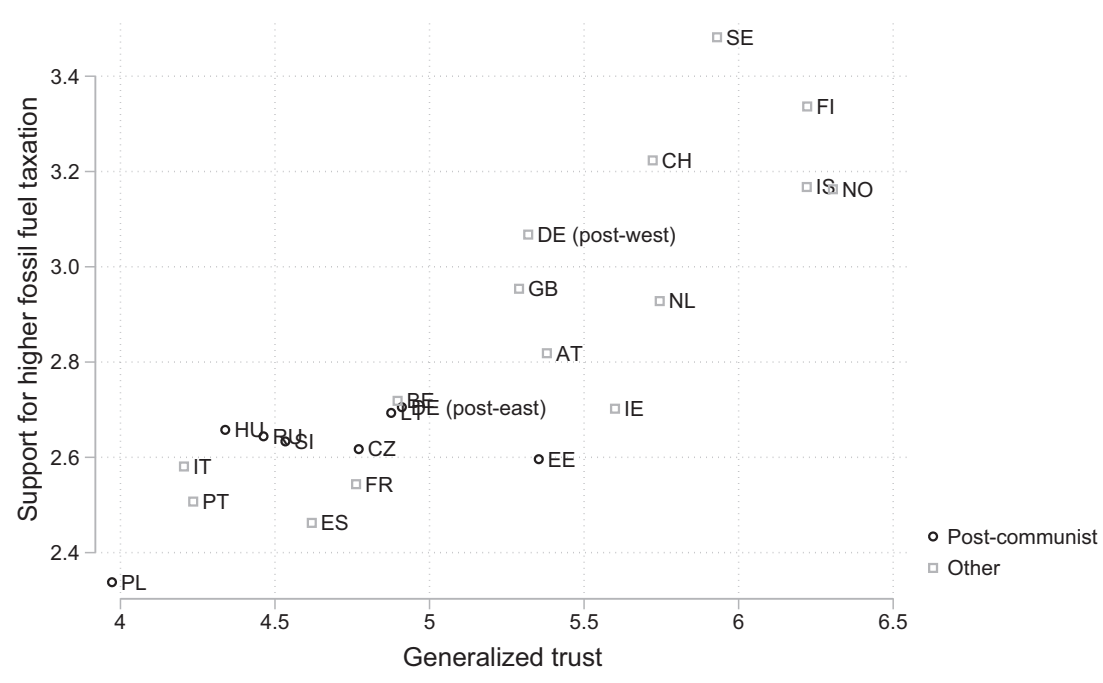

Pearson correlation coefficient between $X$ and $Y$ variables (country averages): 0.8613

Predictors of fossil fuel taxation attitudes

1355

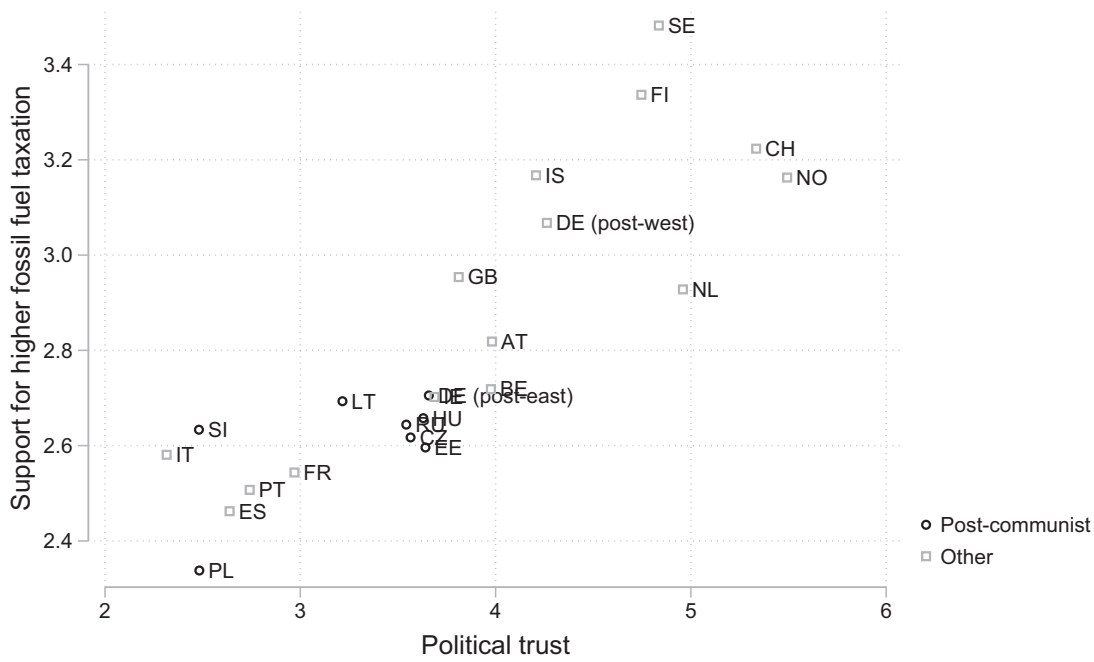

Pearson correlation coefficient between $X$ and $Y$ variables (country averages): 0.8540

Figure A4. Country level averages of political trust and fossil fuel taxation attitudes

\section{Corresponding author}

Jukka Sivonen can be contacted at: jukka.e.sivonen@utu.fi

For instructions on how to order reprints of this article, please visit our website:

www.emeraldgrouppublishing.com/licensing/reprints.htm

Or contact us for further details: permissions@emeraldinsight.com 